$1-1-2006$

\title{
Origin, Scope, and Irrevocability of the Manifest Disregard of the Law Doctrine: Second Circuit Views
}

\author{
Christian Turner \\ University of Georgia School of Law, cmturner@uga.edu \\ Joshua Ratner
}

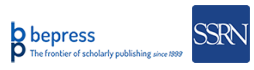

\section{Repository Citation}

Christian Turner and Joshua Ratner, Origin, Scope, and Irrevocability of the Manifest Disregard of the Law Doctrine: Second Circuit Views (2006),

Available at: https://digitalcommons.law.uga.edu/fac_artchop/644

This Article is brought to you for free and open access by the Faculty Scholarship at Digital Commons @ University of Georgia School of Law. It has been accepted for inclusion in Scholarly Works by an authorized administrator of Digital Commons @ University of Georgia School of Law. Please share how you have benefited from this access For more information, please contact tstriepe@uga.edu. 


\title{
Second Circuit Survey
}

\author{
ORIGIN, SCOPE, AND IRREVOCABILITY OF THE MANIFEST \\ DISREGARD OF THE LAW DOCTRINE: SECOND CIRCUIT \\ VIEWS
}

By Joshua Ratner and Christian Turner ${ }^{*}$

\begin{abstract}
After arbitration has occurred, parties may seek judicial enforcement of the arbitral award, converting the private determination into an enforceable judgment. Parties that did not prevail in the arbitration may, at the same time, seek to have the arbitral award vacated. This article concerns the doctrine that permits courts to vacate an arbitral award when the arbitrators "manifestly disregarded" the law, focusing on recent developments in the Second Circuit. Despite the exceedingly deferential scope of this doctrine, the Second Circuit has actually vacated a handful of arbitrations on grounds of manifest disregard, and the doctrine is routinely raised by litigants.

Importantly, there has been no consistent judicial explanation of the doctrine's source. Courts have variously described manifest disregard review as being statutory and extra-statutory, with hints that it is a critical element of due process. As we will see, a proper understanding of the authority for the doctrine helps answer other questions, such as whether parties can agree to eliminate or strengthen the level of judicial scrutiny of awards.
\end{abstract}

Joshua Ratner is an attorney practicing in New York and Connecticut. Christian Turner is a Visiting Assistant Professor at Fordham Law School. Both are former associates of Wiggin and Dana LLP, where this article was initially conceived and written. Mr. Turner was also supported by a Summer Research Grant from Fordham Law School. The authors would like to thank Jonathan Freiman, Counsel at Wiggin and Dana, as well as the other arbitration-law experts in the firm's Appellate Practice Group, for their assistance with this article. The authors would also like to thank Cole Duncan and the staff of the Quinnipiac Law Review for their editorial assistance. 
We begin by examining the statutory backdrop, the Federal Arbitration Act. Instead of stabilizing the body of arbitration law, the statute seems only to keep the pendulum of contested issues swinging. We focus in particular on the purposes the statute is said to advance, and we criticize the notion that the statute compels courts actively to favor arbitration. The statute is better understood as an antidiscrimination provision, protecting parties' voluntary agreements to arbitrate, or not to arbitrate, from judicial hostility to private adjudication.

With the statute as background, we turn to three important issues the Second Circuit has recently considered, each of which helpfully illuminates the role of public courts in arbitration. The first issue is that the Second Circuit has identified manifest disregard as an extrastatutory form of judicial review, thus breaking from other circuits and from some of its earlier decisions. Although the issue does not appear to have been the subject of much focus, it has great consequence both for determining whether the doctrine is mandatory and whether it preempts conflicting state law.

The second issue, building on the first, is whether parties may voluntarily choose either to eliminate review for manifest disregard or to permit review for error (which, as we will discuss, is a level of scrutiny foreign to the statutory scheme). The Second Circuit has held that parties may not prohibit courts from engaging in manifest disregard review. The circuits are divided as to whether parties may compel courts to engage in stricter review of arbitral awards than is provided either by the strict language of the Federal Arbitration Act or the manifest disregard doctrine.

The third and last issue is the ephemeral rise and fall of the doctrine of manifest disregard of the evidence. Determining the limited instances when judges may examine the factual record developed at arbitration provides another opportunity to understand what courts mean by manifest disregard of the law.

We conclude by noting the infrequency of vacatur for manifest disregard, asking whether the doctrine makes much difference. As it is understood by most circuits (a prohibition on arbitrators' conscious disregard of clearly established governing law), it is perhaps not surprising that true "manifest disregard" does not frequently arise. Though, given the supposed tendency of arbitration to favor equitable results, it would be similarly unsurprising if instances of manifest disregard arose commonly. But regardless of its frequency, the doctrine is, obviously, critical to those few cases in which arbitrators have 
consciously disregarded the law. Moreover, the doctrine has helped to illuminate the meaning of modern arbitration, as is shown by the somewhat tangled thicket of issues we discuss. Whether its source is statutory, compelled by due process, or imposed by judges seeking to ensure fundamental fairness, the courts have crafted the doctrine to ensure some basic level of fair treatment. In so doing, they have helped to illuminate the conflicting views of the proper role for public courts in private arbitrations.

\section{THE FUNCTIONAL ROLE OF THE STATUTORY BACKDROP}

After an arbitral award has been made, the prevailing party may go to court to obtain an enforceable judgment for the amount of the award. While there are various theories under the common law by which such judgments could be obtained, ${ }^{1}$ actions to enforce arbitration awards are now set out by statute. Chief among these statutes is the Federal Arbitration Act. ${ }^{2}$

The FAA, or the United States Arbitration Act, was passed as legislatures and courts were embracing arbitration and seeking to extirpate the "ancient judicial hostility to arbitration." ${ }^{\text {It }}$ is perhaps best

1. See, e.g., Kenneth S. Carlston, Theory of the Arbitration Process, 17 LAW \& CONTEMP. PROBS. 631 (1952); Nathan Isaacs, Two Views of Commercial Arbitration, 40 HARV. L. REV. 929 (1926); Addison C. Burnham, Arbitration as a Condition Precedent, 11 HARV. L. REV. 234 (1897). Despite the availability of statutory procedures to convert arbitral awards into publicly enforceable judgments, we believe that an understanding of these common-law theories is critical to figuring out how best to resolve specific questions that may arise in arbitration cases. We will leave the defense of this notion for another article.

2. 9 U.S.C. $\S \S 10,11$. Most states have arbitration statutes based on the Uniform Arbitration Act (or Revised Uniform Arbitration Act), which is similar in most respects to the FAA. See Timothy J. Heinsz, The Revised Uniform Arbitration Act: Modernizing, Revising, and Clarifying Arbitration Law, 2001 J. DISP. RESOL. 1 (2001); Noah Rubins, "Manifest Disregard of the Law" and Vacatur of Arbitral Awards in the United States, 12 AM. REV. INT'L ARB. 363, 365 (2001). State arbitration law, however, is subject to conflict preemption. See, e.g., Doctor's Assocs., Inc. v. Casarotto, 517 U.S. 681, 688 (1996) (holding that a state law was "inconsonant with, and [was] therefore preempted by, the [FAA]" and contrasting the state law with one found to be consistent with the FAA and not preempted); Aceros Prefabricados, S.A. v. TradeArbed, Inc., 282 F.3d 92, 100 (2d Cir. 2002) (noting the preemption, as inconsistent with the FAA, of state rules that discriminate against arbitration agreements as compared to other agreements). For a history of the statutory arbitration schemes, see Amy J. Schmitz, Ending a Mud Bowl: Defining Arbitration's Finality Through Functional Analysis, 37 GA. L. REV. 123, 133-56 (2002).

3. Mastrobuono v. Shearson Lehman Hutton, Inc., 514 U.S. 52, 56 (1995) (quotation 
understood as an anti-discrimination statute, as its primary goal was to place arbitration agreements on the same footing as other contractual provisions. The House Report summarized the atmosphere succinctly:

The need for the law arises from an anachronism of our American law. Some centuries ago, because of the jealousy of the English courts for their own jurisdiction, they refused to enforce specific agreements to arbitrate upon the ground that the courts were thereby ousted from their jurisdiction. This jealousy survived for so long a period that the principle became firmly embedded in the English common law and was adopted with it by the American courts. The courts have felt that the precedent was too strongly fixed to be overturned without legislative enactment, although they have frequently criticised the rule and recognized its illogical nature and the injustice which results from it. This bill declares simply that such agreements for arbitration shall be enforced, and provides a procedure in the Federal courts for their enforcement. ${ }^{4}$

The arbitration statutes do not, however, contain only bare prohibitions against judicial discrimination. They prescribe procedures by which courts must compel, confirm, or vacate arbitrations. In this respect the acts resemble statutes like the Voting Rights Act, endeavoring to prevent certain institutional conduct not merely by outlawing it, but by setting forth particular non-discriminatory, nondiscretionary procedures that the institution must follow. ${ }^{5}$ If a judge is able to vacate an arbitration award only if certain statutory conditions are met, then there is no room for the judge to declare the arbitration void on discriminatory grounds.

However, courts have also written, unfortunately without qualification, that the FAA embodies a "strong federal policy in favor of arbitration." Although the FAA's legislative history does contain

marks omitted). This statement of the FAA's purpose is intoned often when the Supreme Court decides an arbitration case. See, e.g., E.E.O.C. v. Waffle House, Inc., 534 U.S. 279, 289 (2002) (stating that the FAA's "purpose was to reverse the longstanding judicial hostility to arbitration agreements that had existed at English common law and had been adopted by American courts, and to place arbitration agreements upon the same footing as other contracts" (quoting Gilmer v. Interstate/Johnson Lane Corp., 500 U.S. 20, 24 (1991)); Circuit City Stores, Inc. v. Adams, 532 U.S. 105, 118 (2001); Green Tree Financial Corp-Alabama v. Randolph, 531 U.S. 79, 89 (2000). For more on the attitudes that prevailed before the passage of these statutes, see Schmitz, supra note 2, at 137-43.

4. H.R.Rep. No. 96, 68th Cong., 1st Sess., 1-2 (1924).

5. See, e.g., Tennessee v. Lane, 541 U.S. 509, 519 n.4 (2004) (citing a range of cases defining the extent of congressional power to proscribe constitutional conduct and to legislate procedures in order to prohibit and deter unconstitutional conduct).

6. E.g., Shearson/American Exp., Inc. v. McMahon, 482 U.S. 220, 227 (1987) 
statements touting the supposed benefits of arbitration, ${ }^{7}$ believing that there is a bedrock policy of preferring arbitration to public litigation is both unnecessary to understanding the substance and procedure of modern arbitration law and at odds with actual doctrine. There is a "strong federal policy" in favor of enforcing parties' agreements to arbitrate. But that is a very different policy position, and one that merely restates the antidiscrimination principle. Enforcing arbitration agreements requires courts to construe ambiguities in favor of both arbitration and the decisions of arbitrators, else litigation could become protracted, entangling the dispute in public courts and defeating the parties' expressed contractual intent. But this presumption exists only to give effect to voluntary agreements to resort to arbitration, not to shunt as many cases as possible into the private realm.

For example, though courts generally resolve all doubts in favor of giving full effect to the parties' agreement to arbitrate, they do not put a thumb on the scale in favor of arbitration where there is doubt whether the parties elected it. In First Options of Chicago, Inc. v. Kaplan, Justice

(quotation marks omitted). Most such declarations cite Moses $\mathrm{H}$. Cone Memorial Hosp. v. Mercury Const. Corp., 460 U.S. 1, 24-25 (1983), for support. Moses H. Cone in turn relies on various circuit court opinions. Tracing the line of precedent back from these cases does reveal some that advance the empirical claim that arbitration is faster and cheaper than public litigation and the implicit normative claim that it is better. See, e.g., Robert Lawrence Company v. Devonshire Fabrics, Inc. 271 F.2d 402, 410 (2d Cir. 1959) ("[D]oubts as to the construction of the Act ought to be resolved in line with its liberal policy of promoting arbitration both to accord with the original intention of the parties and to help ease the current congestion of court calendars."); Wabash Ry. Co. v. American Refrigerator Transit Co., 7 F.2d 335, 351 (8th Cir. 1925) ("Arbitration is favored by the courts. It is a mode of settling disputes less expensive and more expeditious than court procedure. In these days of long drawn out litigation and ever-increasing expense of trial, it may well become a special favorite of the law."). Still, though, even in these decisions the focus is on providing justification for forcing courts to treat arbitration agreements the same as other contractual agreements. See, e.g., Kulukundis Shipping Co., S/A, v. Amtorg Trading Corporation, 126 F.2d 978, 985 (2d Cir. 1942) (citing and quoting the legislative history to conclude that "[t]he purpose of that Act was deliberately to alter the judicial atmosphere previously existing"). In the course of deciding that arbitration must be ordered even when it would result in less efficient, bifurcated proceedings, the Supreme Court wrote: "The legislative history of the Act establishes that the purpose behind its passage was to ensure judicial enforcement of privately made agreements to arbitrate. We therefore reject the suggestion that the overriding goal of the Arbitration Act was to promote the expeditious resolution of claims. The Act, after all, does not mandate the arbitration of all claims, but merely the enforcement- upon the motion of one of the parties-of privately negotiated arbitration agreements." Dean Witter Reynolds, Inc. v. Byrd, 470 U.S. 213,219 (1985).

7. "It is practically appropriate that the action should be taken at this time when there is so much agitation against the costliness and delays of litigation. These matters can be largely eliminated by agreements for arbitration, if arbitration agreements are made valid and enforceable." H.R.Rep. No. 96, 68th Cong., 1st Sess., 2 (1924). 
Breyer noted that when a dispute concerns whether an arbitration clause reaches a particular issue, then the law rightly "insist[s] upon clarity before concluding that the parties did not want to arbitrate a related matter." 8 This presumption is reversed, however, when the issue is that of arbitrability itself. When a party claims that a contract requires the arbitrators, and not courts, to decide whether a particular issue is arbitrable, courts will require "clear and unmistakable" evidence that the parties so agreed before compelling arbitration of the issue of arbitrability. ${ }^{9}$ This rule is an application of the principle that parties can be forced to arbitrate "only those issues [they] specifically ha[ve] agreed to submit to arbitration" to a context in which it is doubtful that the parties contemplated the question. ${ }^{10}$

If there were truly a federal policy "in favor" of arbitration, preferring and promoting arbitration over judicial resolution, one would not expect courts to require clear and unmistakable evidence of a party's consent to arbitration before ordering it. Rather, doubt as to consent would be resolved in favor of the government's preferred forum. But that is not the policy. It is the enforcement of parties' agreements to arbitrate in equal measure to other agreements that is the true object of the arbitration statutes. "[T] make arbitration agreements as enforceable as other contracts, but not more so." 11 It is only the potential frustration of the parties' expressed intent that should lead courts to make presumptions in favor of arbitration.

It is important for understanding the decisions discussed below to bear in mind that courts have (properly) determined that rules concerning courts' adjudication of arbitration disputes are best understood as intended to effectuate the parties' intent, not necessarily to uphold arbitral awards at any cost. That said, great deference to the award is essential to protecting the parties' goals in selecting arbitration, lest public court proceedings to enforce the award become trials on the merits, merely adding another layer of fighting to what the parties intended to resolve privately.

8. 514 U.S. 938,945 (emphasis in original).

9. Id.

10. Id.

11. Prima Paint Corp. v. Flood \& Conklin Mfg. Co., 388 U.S. 395, 404 n.12 (1967); cf. Volt Info. Scis. v. Bd. of Trustees, 489 U.S. 468, 476 (1989) ("There is no federal policy favoring arbitration under a certain set of procedural rules; the federal policy is simply to ensure the enforceability, according to their terms, of private agreements to arbitrate."). 


\section{MANIFEST DISREGARD AS A GROUND FOR VACATUR}

\section{A. Manifest Disregard Defined}

The FAA sets forth various grounds for which a district court may vacate an arbitral award. The first three involve instances of obvious misconduct or conflict of interest and do not, at least do not obviously, have anything to do with review for the mere correctness of the arbitrators' decision. ${ }^{12}$ The last, however, permits vacatur when "the arbitrators exceeded their powers, or so imperfectly executed them that a mutual, final, and definite award upon the subject matter submitted was not made."13 Arbitrators have only those powers invested in them by the submission to arbitration, whether in the form of a post-dispute submission or of the arbitration clause itself. ${ }^{14}$ Thus, whether arbitrators exceeded their powers would appear to turn on whether they have done something the agreement expressly prohibited or decided an issue over which the agreement gave them no power. ${ }^{15}$

The Second Circuit has held that arbitrators have exceeded their powers when they decide an issue but lack the "power, based on the parties' submissions or the arbitration agreement, to reach [that] issue."16 The question is whether the arbitration agreement gave the power to the arbitrator to decide an issue, "not whether the arbitrator correctly decided that issue." 17

The FAA does not on its face appear to provide for vacatur when the arbitrators have decided an issue properly before them but decided it terribly wrong. The cases and commentary are legion with permutations of the rationale for this omission: If courts were to review arbitrations with any modicum of scrutiny, it would undercut the primary reason for

12. 9 U.S.C. $\S 10(a)(1)$-(3) (permitting vacatur in cases of fraud, corruption, or arbitrators' bias or misbehavior).

13. 9 U.S.C. $\S 10(a)(4)$.

14. See, e.g., 187 Concourse Assoc's v. Fishman, 399 F.3d 524, 527 (2d Cir. 2005) (holding that the arbitrator exceeded his authority under the collective bargaining agreement containing the arbitration clause and under the submission to arbitration when he reinstated an employee who had been terminated for "just cause" but where the terms of the submission did not authorize any remedy if "just cause" were found).

15. We make no attempt in this Article to parse or discuss the "imperfect[] execut[ion]" ground for vacatur.

16. Westerbeke Corp. v. Daihatsu Motor Co., 304 F.3d 200, 220 (2d Cir. 2002).

17. Hoeft v. MVL Group, Inc., 343 F.3d 57, 71 (2d Cir. 2003). 
arbitration-to prevent public litigation. ${ }^{18}$

Enter Wilko v. Swan. ${ }^{19}$ In the course of deciding that parties could not elect to arbitrate claims under the Securities Exchange Act, a decision that was later overruled, ${ }^{20}$ the Court argued that erroneous applications of the Act by arbitrators would possibly go uncorrected, therefore bolstering the position that Congress did not intend for claims under the act to be arbitrated. The following passage of dicta spawned the much debated issue of whether manifest disregard of the law is grounds for vacatur:

Power to vacate an award is limited. While it may be true, as the Court of Appeals thought, that a failure of the arbitrators to decide in accordance with the provisions of the Securities Act would constitute grounds for vacating the award pursuant to section 10 of the Federal Arbitration Act, that failure would need to be made clearly to appear. In unrestricted submission, such as the present margin agreements envisage, the interpretations of the law by the arbitrators in contrast to manifest disregard are not subject, in the federal courts, to judicial review for error in interpretation. The United States Arbitration Act contains no provision for judicial determination of legal issues such as is found in the English law. ${ }^{21}$

Justice Jackson wrote in concurrence that he found "it unnecessary in this case, where there has not been and could not be any arbitration, to decide that the Arbitration Act precludes any judicial remedy for the

18. Obviously, the rationale is often claimed to be the increased efficiency that is often thought to accompany final, private decision-making. But that is not the only reason parties might have to avoid public courts. See Brad A. Galbraith, Vacatur of Commercial Arbitration Awards in Federal Court: Contemplating the Use and Utility of the "Manifest Disregard" of the Law Standard, 27 IND. L. REV. 241, 243-45 (1993) (citing simplicity, privacy, and the opportunity to select arbitrators with specialized expertise). Whether any of these benefits are great, slight, or non-existent, see id. at 245 (citing C. Evan Stewart, Dissenting Voice on Securities Arbitration, LEGAL TIMES, Aug. 21, 1989), is not the point. Whatever the reason parties may have to choose private arbitration, it will be undermined if review de novo can be had in a public court; all that would be added by arbitration is another layer of adjudication. Thus, because this article is not directed at evaluating the justifications parties might have for choosing arbitration, we can simplify the analysis by noting that all who so choose do so to avoid public litigation.

19. 346 U.S. 427 (1953).

20. Rodriguez de Quijas v. Shearson/American Exp., Inc., 490 U.S. 477 (1989). Notably, the Rodriguez Court observed that the Wilko Court's arguments that arbitrators were not equipped to adjudicate claims under the Act manifested the very sort of distrust of arbitrators that the FAA was meant to eradicate. Id. at 480.

21. Wilko, 346 U.S. at 436-37 (footnotes omitted). 
arbitrators' error of interpretation of a relevant statute."22 The Justices in dissent noted that arbitrators "may not disregard the law" and that their failure to observe the law would be grounds for vacatur." ${ }^{23}$ Thus, all Justices, if Justice Jackson's concurrence is read for what it implies of his views, appeared to agree that, at the very least, arbitrators' disregard of the governing law (or at least statutory rights) would subject their award to vacatur.

However, the strongest possible reading of these dicta has not prevailed. Parties to arbitration have no ability to overturn an award for simple, or even egregious, errors of law or fact. Rather, the doctrine of "manifest disregard" has been restricted to instances of arbitrators' intentional obstinance. That is, the doctrine applies only when it is manifest that the arbitrators appreciated the law that ought to have governed but intentionally disregarded it.

The Second Circuit first mentioned the Wilko dicta nearly half a century ago in Amicizia Societa Navegazione v. Chilean Nitrate Corp. ${ }^{24}$

22. Id. at 438-39.

23. Id. at 440 .

24. 274 F.2d 805, 808 (2d Cir.1960). The Second Circuit reached similar dispositions in cases decided in the next decade, doubting or even ruling against the petitioners on the merits and also noting that the grounds for vacatur are limited and would preclude relief even if error had occurred. See, e.g., S.E. Atlantic Shipping Ltd. v. Garnac Grain Co., 356 F.2d 189, 191-92 (2d Cir. 1966); Saxis S. S. Co. v. Multifacs Int'l Traders, Inc., 375 F.2d 577, 581 82 (2d Cir. 1967); Fed. Commerce \& Nav. Co. v. Kanematsu-Gosho, Ltd., 457 F.2d 387, 38990 (2d Cir. 1972); Office Of Supply, Gov't. of the Republic Of Korea v. N.Y. Navigation Co., 469 F.2d 377, 379-80 (2d Cir. 1974). In Sobel v. Hertz, Warner \& Co., 469 F.2d 1211 (2d Cir. 1972), a stock purchaser-broker dispute, the court discussed the manifest disregard standard in the course of deciding whether the arbitration should be vacated on account of the arbitrator's failure to supply reasons for their award. The purchaser contended that "unless the arbitrators explained their decision, there was no way of telling whether it was in "manifest disregard' of the provisions of the securities acts." Id. at 1213. In the course of deciding arbitrators had no obligation to supply reasons for their awards, the court cited the Wilko dicta and wrote:

[I]f the arbitrators simply ignore the applicable law, the literal application of a "manifest disregard" standard should presumably compel vacation of the award. The problem is how a court is to be made aware of the erring conduct of the arbitrators. Obviously, a requirement that arbitrators explain their reasoning in every case would help to uncover egregious failures to apply the law to an arbitrated dispute. But such a rule would undermine the very purpose of arbitration, which is to provide a relatively quick, efficient and informal means of private dispute settlement.

Id. at 1214. It might have been better for the court to have written that a mandatory rule requiring written opinions would interfere with the intention of many parties to forego such formalities. Whether or not requiring opinions would actually make arbitrations slower or less efficient, it would limit the parties' ability to define the scope of the arbitrators' duties. 
There, the court brushed aside the petitioner's claim that the arbitrators had manifestly disregarded the law, doubting whether the arbitrators had committed any error and noting that even if they had "the misapplication ... [of] rules of contract interpretation does not rise to the stature of a 'manifest disregard' of law."25

The Second Circuit's first difficult analysis of the Wilko dicta and the manifest disregard standard came in In re I/S Stavborg v. Nat'l Metal Converters, Inc., a shipping dispute over payment of freight. ${ }^{26}$ The court described its predicament thusly: "Faced . . . with a reasoned opinion that is, in our view, clearly erroneous both in logic and result [in its interpretation of the underlying contract], we are confronted with the question whether it is nevertheless our obligation under the Federal Arbitration Act to affirm the award."27 The court concluded that it was obligated to confirm the erroneous award. Noting that manifest disregard review may signify no more than review under the grounds enumerated by the FAA, the court concluded that "[w]hatever arbitrators' mistakes of law may be corrected, simple misinterpretations of contracts do not appear one of them." ${ }^{28}$ Thus, it left for another day the task of specifying what, precisely, would constitute manifest disregard of the law.

Eventually, the Second Circuit did arrive at a concise and wellspecified formulation of the standard that neatly tracks the ordinary meaning of "manifest disregard of the law." 29 Noting that "[a]lthough the bounds of this ground ha[d] never been defined, it clearly means more than error or misunderstanding with respect to the law."30 Although courts may vacate an award on account of the arbitrators' deciding, in manifest disregard of the law, an issue that is clearly within their power to decide, they will do so only when "(1) the arbitrators knew of a governing legal principle yet refused to apply it or ignored it altogether and (2) the law ignored by the arbitrators was well defined, explicit, and clearly applicable." 31 This formulation tests not for error

25. Id.

26. 500 F.2d 424 (2d Cir. 1974)

27. Id. at 429.

28. Id. at 431-32.

29. Merrill Lynch, Pierce, Fenner \& Smith, Inc. v. Bobker, 808 F.2d 930, 933-34 (2d Cir. 1986).

30. Id. at 933 .

31. Hardy v. Walsh Manning Securities, L.L.C., 341 F.3d 126, 129 (2d Cir. 2003) (punctuation omitted). For a helpful circuit-by-circuit rundown of manifest disregard standards, see John H. Binning and Robert L. Nefsky, Vacating Arbitration Awards, ARIAS Q. 
but for arbitrators' clear obstinance in the face of controlling law. ${ }^{32}$ The Second Circuit's standard, with slight variations, is used by most circuits. $^{33}$

\section{B. Source of Authority}

It is in section 10 of the FAA that the Wilko majority and dissent locate the source of authority by which a court may vacate an arbitration award for manifest disregard of the law. Presumably, to disregard the governing law would be to exceed one's powers as an arbitrator, but the Justices did not state precisely what in section 10 authorized this review. Other courts, both federal and state, have also stated that manifest disregard review is an application of section 10 (and its state analogues). ${ }^{34}$ Indeed, not long after Wilko, the Second Circuit wrote: "It is true that an award may be vacated where the arbitrators have 'exceeded their powers.' Apparently relying upon this phrase, the Supreme Court in Wilko $v$. Swan, suggested that an award may be vacated if in 'manifest disregard' of the law." 35 If that is the case, then the obligation to follow the governing law is a restriction on the

MAG., Second Quarter, at 18 (2002).

32. There are two types of "clarity" courts could insist upon. First, the applicable law must be clear and clearly applicable. This has nothing to do with what occurs in the arbitration itself but is a question of the state of the law. Second, courts could require a clear mismatch between the law as presented to the arbitrators and the law the arbitrators apply. This is a question of what the arbitrators were told and what they did.

33. The Seventh Circuit is an outrider, being particularly hostile to "manifest disregard" as an independent basis for review. After Justice Breyer's citation of the Wilko dicta in First Options, 514 U.S. at 942, the Seventh Circuit held that an award is in manifest disregard of the law only if it requires a party to violate the law. George Watts \& Son, Inc. v. Tiffany and Co., 248 F.3d 577, 581 (7th Cir. 2001). Though its discomfort with the manifest disregard standard may be sensible, see infra, the panel's formulation of the standard is difficult to understand. While an award directing a party to break the law would surely be subject to vacatur under the statute, to hold that only such awards are in "manifest disregard of the law" is to give a highly unnatural meaning to that phrase.

34. See, e.g., Kyocera Corp. v. Prudential-Bache Trade Servs., Inc., 341 F.3d 987, 997 (9th Cir. 2003) (en banc) (stating that an award in manifest disregard of the law is in excess of the arbitrators' powers and citing § 10(a)(4)); Garrity v. McCaskey, 223 Conn. 1, 11 (1992).

35. Amicizia Societa Navegazione v. Chilean Nitrate Corp, 274 F.2d 805, 808 (2d Cir. 1960); see also IN Stravborg, 500 F.2d at 431 ("But perhaps the rubric 'manifest disregard' is after all not to be given independent significance; rather it is to be interpreted only in the context of the specific narrow provisions of 9 U.S.C. $\S \S 10 \& 11$, as Chief Judge Clark's opinion for this court indicated in [Amicizia]" (citation omitted)). 
authority of the arbitrator's power that is to be read into the arbitration clause itself, even when no such express limitation exists. ${ }^{36}$

But contrary to these authorities and its own earlier characterizations of the doctrine's origins, the Second Circuit in Hoeft $v$. MVL Group, Inc., described the doctrine as "an additional ground not prescribed by statute." ${ }^{37}$ Judge Parker wrote that the Supreme Court in Wilko had "supplemented" the FAA with the requirement that arbitral decisions not be in manifest disregard of the law. Other courts and commentators have also described manifest disregard as an extrastatuory ground for vacatur. ${ }^{38}$

Charting a sort of middle course, the Alabama Supreme Court has held that manifest disregard review is nonstatutory but, in the doctrine's defense, is essential to the statutory scheme and the FAA's goals:

One need only consider the complexity of legal theories and the large sums of money involved in the cases now before us to realize that failure to provide the additional, albeit extremely limited, nonstatutory ground of review of a manifest disregard of the law for the review of an arbitration award could

36. Another interpretation that is functionally equivalent to the "exceeding authority" theory of manifest disregard is given by Professor Stephen Hayford. See Stephen L. Hayford, Law in Disarray: Judicial Standards for Vacatur of Commercial Arbitration Awards, 30 GA. L. REV. 731, 816-19 (1996). According to Professor Hayford, manifest disregard is better thought of as the willful refusal by an arbitrator to apply the governing law or as a form of arbitral misconduct justifying vacatur under 9 U.S.C. $\& 10(a)(3)$. Whichever statutory view one takes, whether misconduct or the exceeding of authority, "vacatur of the award transpires, not because the arbitrator made an error of law . . . but rather because she ignored the law." Id. at 817 .

37. 343 F.3d 57, 64 (2d Cir. 2003). The Second Circuit reached the same conclusion in Duferco Int'l Steel Trading v. T. Klaveness Shipping A/S Stark, 333 F.3d 383, 389 (2d Cir. 2003), describing manifest disregard as "a doctrine of last resort -its use is limited only to those exceedingly rare instances where some egregious impropriety on the part of the arbitrators is apparent but where none of the provisions of the FAA apply." The first description by the Second Circuit of manifest disregard review as extra-statutory, breaking with its description in previous cases, appears to have come in Office Of Supply, Gov't. of the Republic Of Korea v. N.Y. Navigation Co., 469 F.2d 377, 380 (2d Cir. 1974). There the court described the doctrine as a "severely limited . . . judicially-created addition to the proscriptions of 9 U.S.C. $\S 10 . "$ Id.

38. See, e.g., Brabham v. A.G. Edwards \& Sons, Inc., 376 F.3d 377, 381 (5th Cir. 2004); Noah Rubins, "Manifest Disregard of the Law" and Vacatur of Arbitral Awards in the United States, 12 AM. REV. INT'L ARB. 363, 366 (2001); Eric van Genkel, Reframing the Dilemma of Contractually Expanded Judicial Review: Arbitral Appeal vs. Vacatur, 3 PEPP. DISP. RESOL. L.J. 157, 211 (2003). But see Hayford, supra note 36, at 813, 816-19 (describing much manifest disregard litigation as consisting of arguments for extrastatutory review but suggesting that review for true manifest disregard, which is not concerned with review for error, is justified as review for arbitral misconduct under the FAA). 
potentially conflict with the goals and policies of the FAA. Carte blanche judicial approval of decisions rendered by arbitrators not shown to have been guilty of fraud, partiality, or corruption and not made "in excess of the arbitrator's powers," but that egregiously and manifestly depart from clearly established law of which the arbitrators were patently aware, would serve only to undermine the public's confidence in the arbitration process. ${ }^{39}$

Still others have simply noted that the source of the doctrine is unclear. ${ }^{40}$ The Second Circuit has itself highlighted the overlap between "exceeding authority" and "manifest disregard" forms of review. In Duferco, despite stating that manifest disregard review can be used only when "none of the provisions of the FAA apply," 41 the court wrote that three of the four cases in which it had held that arbitrators had manifestly disregarded the law could have been decided on exceeding authority grounds. ${ }^{42}$ Indeed, courts have applied tests for exceeding authority and manifest disregard without distinguishing the doctrines. ${ }^{43}$

Taking a dim view of the doctrine's source, whatever it was, Judge Posner derided manifest disregard review as alternatively unnecessary or just plain wrong:

We can understand neither the need for the ["manifest disregard"] formula nor the role that it plays in judicial review of arbitration (we suspect none-that it is just words). If it is meant to smuggle review for clear error in by the back door, it is inconsistent with the entire modern law of arbitration. If it is intended to be synonymous with the statutory formula that it most nearly resembles—-whether the arbitrators "exceeded their powers"-it is superfluous and confusing. There is enough confusion in the law. The grounds for setting aside arbitration awards are exhaustively stated in the statute.

Judge Posner may have been too quick to dismiss the manifest disregard standard. "Exceeding authority" is a rather broad label. It does not seem "superfluous" or "confusing" to explicate how a standard

39. Birmingham News Co. v. Horn, 901 So. 2d 27, 49 (Ala. 2004).

40. See, e.g., Galbraith, supra note 18 , at $256-58$.

41. See supra, note 37.

42. Duferco, 333 F.3d at 389.

43. See, e.g., Missouri River Servs., Inc. v. Omaha Tribe of Neb., 267 F.3d 848, 854-56 (8th Cir. 2001). Often there is no reason to distinguish carefully, as vacatur occurs whatever the ground.

44. Baravati v. Josephthal, Lyon \& Ross, Inc., 28 F.3d 704, 706 (7th Cir. 1994). 
applies to a particular breed of ultra vires act. The Second Circuit standard, for example, could be considered a definition of a species of arbitral conduct that is, per se, in excess of arbitral authority. Rules governing the applications of standards to particular circumstances are useful both for litigants and lower courts. Moreover, if manifest disregard is not a kind of exceeding authority, then it does not necessarily follow that it is review for clear error, as Posner suggests. The Second Circuit standard, for example, is not review for error, even if, as the Second Circuit has held, it is not a proxy for exceeding authority review.

The obvious point to be made in favor of the position that manifest disregard review is an application of the statute is that an arbitrator who "egregiously . . . departs from clearly established law of which the or she] [is] patently aware"45 either is patently in excess of his or her authority or has "misbehav[ed]," causing prejudice within the meaning of section 10(a)(3). And so adopting the Second Circuit standard is tantamount to identifying the standard as statutory, regardless of the fact that the Second Circuit calls it "nonstatutory."

At this point, it may be wondered why it matters whether the doctrine comes from statute or from the thin air somewhere in the confines of the Supreme Court's marble temple. There are at least two reasons. First, if it is not statutory, then it is open to question whether the doctrine should be applied at all when the parties have not expressly, in the arbitration clause and not just the choice of law clause, required arbitrators to comply with the law they have chosen. Perhaps ignoring the law and rendering what the arbitrator believes in good faith to be an equitable compromise would not qualify as "misbehavior" or exceeding the arbitrator's powers, at least where the parties, though choosing a law to govern, did not expressly constrain the arbitrator to the application of that law alone. ${ }^{46}$ Where parties do not expressly state that the arbitrator is duty-bound to follow the governing law, it may often be that they intend to give free reign to the arbitrator to reach an equitable result, using the governing law as a set of guidelines rather than commandments. If this is the case, then manifest disregard doctrine (a)

45. Birmingham News Co. v. Horn, 901 So. 2d 27, 49 (Ala. 2004).

46. This possibility is not as silly as it might at first sound. Mere choice of law clauses have been held not to be sufficient to constrain the arbitrators' authority so as to require their decisions to be consistent with state arbitration law (at least where the arbitration clause opted for procedures arguably inconsistent with the state's arbitration law). See Mastrobuono v. Hutton, 514 U.S. 52, 59-60 (1995). 
does not follow from the grounds for vacatur given in the FAA and (b) is in contradiction with an efficient default rule. ${ }^{47}$

Second, if the standard does not follow from the statute, then states need not apply it and may even be able to apply a stricter standard. After all, the FAA only preempts state arbitration law that is in conflict with it. ${ }^{48}$ If the manifest disregard standard is not a part of the FAA, but also does not conflict with it, then states could be free to adopt it or not. ${ }^{49}$ It would also be open to question whether states could go further and apply even stricter standards of review. The Supreme Court's dicta imply only that manifest disregard review is not barred by the FAA, not that more searching review would not be so barred.

If the doctrine is nonstatutory, what is it? As discussed, supra, the FAA is best viewed as an antidiscrimination statute. It should not be understood to supply the rule for decision on every arbitration issue. Under this approach, the manifest disregard doctrine might be an element of federal common law that courts apply in arbitration cases. This issue is complex, and we will not dwell on it here. ${ }^{50}$ It may also be that due process concerns underlie the doctrine. If that is the case then, for preemption purposes, the doctrine may as well be statutory, in that it will override any inconsistent state law. The Second Circuit's view of the manifest disregard doctrine as nonstatutory obviously leaves many unanswered questions.

\section{May Parties Opt for Stricter or Looser Review?}

If parties cannot silently empower the arbitrator to ignore or supplement the law they have chosen to govern, the natural question is whether they can do so explicitly, contracting out of manifest disregard review. The Hoeft court decided that the answer here again was no.

47. By "efficient default rule," we mean only a rule that succeeds in capturing parties' usual, but unexpressed, intent.

48. See supra, note 2 .

49. That is, unless there is something to the "due process" dicta in Kyocera or lurking in the background in Hoeft. See infra, notes 81-84 and accompanying text.

50. Most arbitration cases in federal court are diversity cases, and so the common law of contracts to be applied should be that of the state whose law governs. We will not here discuss whether there is space between the FAA and the common law of contracts for a common law of arbitration. 
The dispute in Hoeft arose from the stock sale of two market research companies. By agreement, the purchaser, MVL Group, was permitted to delay paying a portion of the purchase price until the following year, and in exchange the sellers, the Hoefts, would be paid an amount based on the increased value of the companies, if any. If the parties were unable to agree as to the companies' value,

such dispute shall be resolved by Steven Sherrill, whose decision in such matters shall be binding and conclusive upon each of the parties hereto and shall not be subject to any type of review or appeal whatsoever. ${ }^{51}$

Of course, there was a disagreement, and Sherrill served as arbitrator, finding in favor of the Hoefts. In the district court on petitions to confirm and to vacate the award, it was urged by MVL Group, inter alia, that Sherrill exceeded his authority and that he manifestly disregarded the law. The district court held that he had not exceeded his authority but that he had manifestly disregarded the law. ${ }^{52}$

On appeal, the Hoefts argued that the court erred by even entertaining the argument that the arbitrator manifestly disregarded the law, as the arbitration clause foreclosed any inquiry into the correctness of the arbitrators' decision. ${ }^{53}$ Their argument apparently relied "on the general principle of freedom of contract and the more specific canon of deference to private agreements to arbitrate."

The Hoeft court's decision not to permit the parties by contract to forego manifest disregard review had several supporting premises. First, the court noted that the safety net of minimal judicial scrutiny undergirds the federal courts' strong support for arbitration. ${ }^{55}$ In support, the court cited the line of cases justifying mandatory arbitration of statutory disputes on account of the sufficiency of the concededly limited judicial review of awards. In other words, the fact that there was at least minimal review of awards was used as an argument to support compelling arbitration of statutory rights. This could mean, though it is not clear, that if that review were eliminated, statutory rights could not be arbitrated, or that, taking the Hoeft court's position, limitations on

51. Hoeft v. MVL Group, Inc., 343 F.3d 57, 60 (2d Cir. 2003) (Emphasis added).

52. Id. at 61-62.

53. Id. at 63.

54. Id.

55. Hoeft, 343 F.3d at 63. 
review of such arbitrations would be ignored. But it is not at all clear that the same result should obtain in standard contract disputes.

In Gilmer v. Interstate Johnson Lane Corp., the case relied on in Hoeft, the Supreme Court wrote that "although judicial scrutiny of arbitration awards necessarily is limited, such review is sufficient to ensure that arbitrators comply with the requirements of the statute at issue." ${ }^{, 56}$ It is arguably the state's interest in ensuring protection of statutory rights that makes relevant the presence of at least some judicial safeguards. Whether the state has a similar interest in ensuring privately created contractual rights is far from clear.

But judicial and congressional reliance on the availability of judicial review was not the Hoeft court's only argument. It also argued that parties are not allowed to dictate to courts how they should review the cases before them. ${ }^{57}$ Within this contention are two separate ideas. First, the court noted that although arbitrations are private, their judicial enforcement, with all of the "potent public legal remedies available to judgment creditors," is not. ${ }^{58}$ Section 10(a) of the FAA contains safeguards that prevent private parties from using the power of the state to enforce arbitral awards "tainted by partiality, a lack of elementary procedural fairness, corruption, or similar misconduct." ${ }^{19}$ The first reason, then, is to prohibit parties from marshaling the compulsory power of the state in circumstances that would violate both the congressional policies expressed in section 10 and judicial norms of fair treatment. This rationale, and the general tenor of the opinion, suggest, though the court does not so state, that it would violate an individual's due process rights to enter a judgment and permit enforcement of that judgment against the individual on account of a patently unfair arbitration.

But later in the opinion, when discussing why parties could not contract around even nonstatutory grounds for vacatur like manifest disregard, the court advanced a subtly different rationale. Quoting the Tenth Circuit's decision in Bowen v. Amoco Pipeline Co. ${ }^{60}$ the court

56. 500 U.S. 20, 32 n.4 (1991) (internal quotation marks omitted).

57. Hoeft, 343 F.3d at $64-65$.

58. Id. at 64 .

59. Id.

60. 254 F.3d 925, 936 n.8 (10th Cir. 2001). The Tenth Circuit's jurisprudence is somewhat complex on this point, however. It has recently held that parties may agree to bar appeals from a district court's review of an arbitration, while distinguishing Hoeft, in dicta, as being concerned with whether parties could agree not to apply those portions of the FAA itself that provide for district court review. See MACTEC, Inc. v. Gorelick, 427 F.3d 821, 827-30 
wrote: "“[I]n the absence of clear authority to the contrary, parties may not interfere with the judicial process by dictating how the federal courts operate." "61 Here the court cites not the injury to the litigants but the interference with the independence of the courts as the danger to be avoided.

This noninterference rationale, that courts' methods of review are laid down in law and are not the prerogative of private litigants, has been the principle relied on by courts that have refused to permit private agreements to raise the level of review of arbitral awards. The decisions in the Ninth Circuit in the Lapine cases are illustrative. In Lapine Technology Corp. v. Kyocera Corp. (Lapine I), ${ }^{62}$ the court faced a singles issue: "Is federal court review of an arbitration agreement necessarily limited to the grounds set forth in the FAA or can the court apply greater scrutiny, if the parties have so agreed?"63 The court concluded that it was bound by the parties' agreement, which specified that the arbitral award could be vacated (1) on any of the FAA's grounds for vacatur, (2) "where the arbitrators' findings of fact are not supported by substantial evidence, or [(3)] where the arbitrators' conclusions of law are erroneous." 64

The Ninth Circuit's holding in Lapine I rested on Supreme Court precedent that emphasized the importance of honoring the parties' agreement above all else in arbitration matters. ${ }^{65}$ Moreover, the court argued, it is not as though the level of review selected by the parties increases the workload of the courts, as the courts would have to adjudicate the entire case in the absence of the arbitration agreement. ${ }^{66}$

In concurrence, Judge Kozinski wrote that the case presented an issue "closer than most." 67 Noting that parties could not by agreement create work for federal courts when Congress has withheld from the courts the power to do that work, Kozinski nevertheless concluded that, given the "strong policy of party empowerment embodied in the

(10th Cir. 2005).

61. Hoeft, 343 F.3d at 65. The court's reliance on Bowen is somewhat troubling as it is perhaps the only case that has directly asserted, though in dicta as the Hoeft court pointed out, that "parties to an arbitration may eliminate judicial review by contract." Bowen, 254 F.3d at 931.

62. 130 F.3d 884 (9th Cir. 1997).

63. Id. at 887.

64. Id.

65. Id. at 888 (citing and relying primarily on Volt Info Scis. v. Bd. of Trustees, 489 U.S. 468 (1989)).

66. Lapine I, $130 \mathrm{~F} .3 \mathrm{~d}$ at 889.

67. Id. at 891 (Kozinski, J., concurring). 
[FAA]," it was "probably enough" that the work the parties had assigned the court in this case was "no different from that performed by the district courts in appeals from administrative agencies and bankruptcy courts, or on habeas corpus."68 "I would call the case differently if the agreement provided that the district court would review the award by flipping a coin or studying the entrails of a dead fowl."

In dissent, Judge Mayer wrote: "Whether to arbitrate, what to arbitrate, how to arbitrate, and when to arbitrate are matters that parties may specify contractually. However, Kyocera cites no authority explicitly empowering litigants to dictate how an Article III court must review an arbitration decision." ${ }^{, 70}$ This rationale is identical to the best argument advanced by the Hoeft court.

After remand, and several years later, the case returned to the Ninth Circuit, which then took the opportunity to overrule, en banc, Lapine I. $^{71}$ The opinion by Judge Reinhardt relied almost exclusively on the noninterference ground that Judge Mayer had set forth. ${ }^{72}$ Several commentators have criticized this approach. Their argument appears to be (a) that the courts' jurisdiction to hear arbitration cases does not arise from the FAA but from diversity, federal question, or some other independent basis, (b) that though the agreement may ask the court to apply a standard that the law nowhere authorizes, the parties are estopped from arguing that the court is powerless to apply the standard, (c) that so long as the agreement "requires" the court to review the award in a manner similar to that to which it is accustomed in any other type of case it may hear, the court is not being converted into a private decision-making body, and (d) that searching review is less burdensome than a trial on the merits, thus making expanded judicial review no more burdensome than would be the court's task if there were no arbitration agreement at all. ${ }^{73}$ These arguments are unconvincing.

The last two, points (c) and (d), are obviously ineffective against a proper argument that the court simply lacks the power to apply the

68. Id.

69. Id.

70. Lapine I, 130 F.3d at 891 (Mayer, J., dissenting).

71. Kyocera Corp. v. Prudential-Bache T Servs. (Lapine II ), 341 F.3d 987, 994 (9th Cir. 2003).

72. Id. at 1000 (" $[\mathrm{P}]$ rivate parties have no power to determine the rules by which federal courts proceed, especially when Congress has explicitly prescribed those standards.").

73. The cases and scholarship on this issue are summarized in Eric van Ginkel, Reframing the Dilemma of Contractually Expanded Judicial Review: Arbitral Appeal vs. Vacatur, 3 PEPP. DISP. RESOL. L.J. 157, 181-86 (2003). 
standard the parties have chosen. The first two are simply irrelevant. As to (a), whether a court has power to hear a case at all is a different question from whether the court has the authority to apply a particular standard. If Congress passed a statute requiring resort to a particular standard, it would not do to claim that the bare fact of the court's jurisdiction over the case permitted the court to ignore the statutorily imposed standard. As to (b), it is certainly true that the impropriety of a court's acting in excess of its statutory jurisdiction may be forfeited as a ground for reversal if it is not timely raised. But that is far different than concluding that parties' agreements prevent them and the courts from enforcing such statutory limitations as an initial matter.

Other courts and commentators have relied on the further ground for prohibiting contractual expansion of judicial review that it is contrary to the policies underlying the FAA. ${ }^{74}$ This is by far the weaker of the two arguments supporting this position, neatly mirroring the strength of the similar lineup of arguments marshaled by Judge Parker in Hoeft. Whether expanded judicial review threatens the finality of arbitration, is less efficient than "standard" review of arbitration awards, or tends, because of its inefficiency, to cause such cases to remain longer on the court's docket than other arbitration enforcement proceedings, ${ }^{75}$ has nothing to do with whether we should allow parties voluntarily to opt for it. Only if one believes that the courts should place a thumb on the scale in favor of arbitration regardless of the parties' intent would these sorts of arguments matter. After all, courts have both (a) not permitted arbitration, despite its efficiency benefits, where the parties have not clearly chosen it and (b) ordered arbitration where it was clear that it would be less efficient than public court proceedings. ${ }^{76}$ The oft-cited benefits of arbitration, debatable as they may be, justify giving private parties the choice whether to arbitrate. These benefits are not sacrosanct, and parties are free to structure their arbitrations in ways that defeat them. ${ }^{77}$

74. See, e.g., Bowen v. Amoco Pipeline Co., 254 F.3d 925, 935-36 (9th Cir. 2001); Jonathan R. Bunch, Arbitration Clauses Should Be Enforced According to Their Terms Except When They Shouldn't Be: The Ninth Circuit Limits Parties' Ability to Contract for Standards of Review of Arbitration Awards, 2004 J. DISP. RESOL. 461, $473-74$ (2004).

75. See, Bowen, 254 F.3d at 934-35; Bunch, supra note 74 at 473-74.

76. See, supra, notes 6-10 and accompanying text.

77. See, e.g., Dean Witter Reynolds, Inc. v. Byrd, 470 U.S. 213, 219 (1985) (holding that arbitration must be ordered even when it would be less efficient than court proceedings and noting that the FAA's purpose was to enforce privately made agreements, not to "promote the expeditious resolution of claims"). 
The Hoeft court distinguished the cases that permitted parties to raise the level of scrutiny given to arbitral awards by stating, without deciding whether it agreed with these authorities, ${ }^{78}$ that "there is a fundamental difference between an agreement to increase the scrutiny that courts apply when considering whether to confirm or vacate an arbitration award and an agreement to prevent courts from reviewing the substance of an arbitration award at all." $"$ Ironically, Judge Reinhardt made precisely the opposite observation in Lapine II:

[T] he the decision to contract for a narrower standard of review than the courts generally apply in the absence of a statutory command is a decision that may be less troublesome than the attempt to contract for a broader standard of review than that authorized by Congress, although we need not resolve that question here. 80

In the end, the Hoeft court came to the simple conclusion that "the manifest disregard standard together with $\S 10(a)$ represent a floor of judicial review of arbitration awards below which parties cannot require courts to go, no matter how clear the parties' intentions." 81 As noted supra, this evokes a sense that due process, or fundamental fairness, is an underlying concern. In Kyocera, Judge Reinhardt, referring to all of the grounds for vacatur, said as much directly: "These grounds afford an extremely limited review authority, a limitation that is designed to preserve due process but not to permit unnecessary public intrusion into private arbitration procedures." 82 However, even a constitutional right can be waived; a court's prerogative not to permit private parties to interfere with its work cannot.

78. These cases are: Lapine I, Roadway Package Sys., Inc. v. Kayser, 257 F.3d 287 (3d Cir. 2001), and Gateway Techs., Inc. v. MCI Telecomms. Corp., 64 F.3d 993 (5th Cir. 1995). These cases all rely, at bottom, on Volt to argue that the Supreme Court has approved parties' opting out of the provisions of the FAA. But, as the contrary authority hold, parties are permitted only to choose the procedures and law governing the arbitration itself, not the federal courts' review of arbitral awards.

79. Hoeft v. MVL Group Inc., 343 F.3d 57, 64 (2nd Cir. 2003).

80. Kyocera Corp. V. Prudential-Bache T Servs. (Lapine II), 341 F.3d 987, 998 n.16 (9th Cir. 2003). (emphasis in original).

81. Hoeft, 343 F.3d at 64.

82. Lapine II, 34I F.3d at 998. 


\section{A Fresh Look}

Whatever the source or binding nature of the doctrine, there is good reason to prohibit arbitrators from patently disregarding the rules of decision the parties have contractually chosen, at least where the parties do not empower the arbitrator to do so. In other words, creating a default presumption that parties have constrained the powers of the arbitrator to the application of the governing law is sensible despite the worry that parties may often intend that arbitrators reach equitable, rather than purely legal, results. Better to require parties to say that arbitrators are not bound than to require them, in every case, to bolster the contract's choice of law clause by explicitly restricting the arbitrators to the chosen law in the arbitration clause. It is easier to understand why this is so if we examine a hypothetical case with far simpler governing rules than is ordinary: a coin toss.

Suppose the parties agreed that any dispute between them arising from an underlying agreement would be resolved by the toss of a coin. Set to one side whether such an agreement would be unenforceable under traditional contract law, ${ }^{83}$ and assume for a moment that this is a valid choice of law clause. ${ }^{84}$ A dispute arises. An arbitration is convened, and the arbitrator tosses the coin. Party A prevails. The arbitrator looks at Party A, then at Party B, and says, "I have decided that in spite of the coin toss, the agreement between you compels a different result. Party A's breach was so clear that it would be unjust not to render an award in favor of Party B. I believe that this is consistent with the spirit, if not the letter of your agreement."

Such a disposition is a clear manifest disregard of the "law" specified by the parties. We do not need to have language in the arbitration clause explicitly preventing the arbitrator from reaching such a result to know that the parties intended to prohibit the arbitrator from doing so. But we confront two issues in generalizing this example to

83. We could always specify a more complex set of rules that is still distinct from public legal regimes but that more closely mirrors them.

84. We are sweeping under the rug some complex issues concerning the meaning of positive law. A coin toss that resolves a dispute about conduct that has already occurred has some clear and fundamental differences from specifications of duties and default rules that characterize the legality or illegality of conduct as it occurs. But again, we could always solve this difficulty by creating a set of rules of decision that work in the usual way of an American legal regime and yet which follows from none of them. Thus, despite the superficial problems with this simple example, it serves its purpose without loss of generality. 
more standard agreements.

First, should the decision whether to vacate this award turn on whether the parties styled the choice of law clause as a constraint on the arbitrator's authority? It is somewhat easier to see here, than in an omnibus choice of law clause, that the arbitrator has not complied with the rules the parties really did intend for him or her to follow. And it might be argued that a general choice of law clause is a much weaker statement of the parties' intent as to any particular rule of law than is an express rule laid down by the parties. ${ }^{85}$ Although it is true that an express constraint on arbitral authority carries far more weight than the incorporation of a large body of law, not all of which the parties could possibly have contemplated, in either case, the parties expressed a set of rules that should govern the resolution of their dispute, and it is a reasonable default limitation on arbitral authority to insist that these rules should not be consciously ignored.

Second, the manifest disregard doctrine was initially developed for, and is often used to justify, arbitrations of disputes concerning public laws. The public's interest in enforcing privately created rules and standards, especially those as silly as this one, is far less than it is in enforcing public laws. ${ }^{86}$ Yet, privately created rules demonstrate much more clearly the parties' intent that those rules govern than does the incorporation of public rules. If the parties intended the rules to be optional, they (a) might not have labored to create them or (b) could have easily made them optional. This example exposes the two ways of viewing manifest disregard: as protective of the public laws, or as protective of the parties' intent. Which view courts adopt will affect their disposition of many subsequent issues.

\section{MANIFEST DISREGARD OF THE EVIDENCE}

In a 1998 decision, Halligan v. Piper Jaffray, Inc., ${ }^{87}$ the Second Circuit appeared to create an additional ground for vacatur where an arbitration award demonstrated "manifest disregard of the evidence." As will be discussed below, despite words of caution from the Second

85. See supra, note 46 .

86. On the other hand, parties often litigate in one jurisdiction having selected another jurisdiction's laws to govern their dispute.

87. 148 F.3d 197 (2d Cir. 1998), cert. denied, 119 S.Ct. 1286 (1999). 
Circuit, litigants and district courts alike embraced Halligan's "manifest disregard of the evidence" language as creating an independent ground for vacatur. In Wallace v. Buttar, ${ }^{88}$ the Second Circuit dealt the "manifest disregard of the evidence" a fatal blow by holding that no such additional ground existed for vacating an arbitration award. The Buttar Court, however, did not go so far as to make arbitral findings of fact sacrosanct, instead leaving the door ajar for judicial review of factual findings to the extent necessary for courts to determine whether an arbitration award constitutes "manifest disregard of the law."

\section{A. Halligan}

In Halligan, the Second Circuit appeared to create a new basis for vacating arbitration awards where the arbitration panel demonstrated "manifest disregard of the evidence." Halligan alleged that Piper Jaffray had wrongfully terminated him on the basis of age, in violation of the Age Discrimination in Employment Act. ${ }^{89}$ The arbitration panel found in favor of the defendant without providing any written explanation of their decision. ${ }^{90}$

After noting the strict standard for manifest disregard review, the court discussed the growing skepticism of "mandatory binding arbitration of employment discrimination disputes as a condition of employment." ${ }^{\text {e1 }}$ The court specifically pointed out that industry selfregulated organizations like the National Association of Securities Dealers (NASD) "have been singled out for criticism because, among other reasons, the role they play in determining the pool of available arbitrators and selecting the arbitrators who will hear a particular discrimination claim against a member firm of the [self-regulatory organization] calls into question the impartiality of the arbitrators selected." 92 This skepticism, the court noted, came from legal scholars, Congress, and the federal courts. ${ }^{93}$ Because the court held in favor of vacating the award on the merits, however, it elected not to address the

88. 378 F.3d 182 (2d Cir. 2004).

89. 29 U.S.C. $\S 621$ et seq. See Halligan, 148 F.3d. at 198.

90. Halligan, 148 F.3d at 200.

91. Id. at 202.

92. Id. (citations omitted).

93. Id. at 202-03. 
movant's general challenge to the propriety of NASD-conducted arbitrations. $^{94}$

Moving to the merits of the movant's claim, the court found that "Halligan presented overwhelming evidence that Piper's conduct . . . was motivated by age discrimination." 95 This evidence included testimony about "repeated discriminatory statements," "powerful evidence of [Halligan's] performance," and "a very strong showing that [Halligan] did not choose the 'option' of quitting but was fired." Additionally, the court stated that the record reflected that both parties had agreed on the applicable law and explained that law to the arbitrators. ${ }^{97}$ As a result, the court held: "In view of the strong evidence that Halligan was fired because of his age and the agreement of the parties that the arbitrators were correctly advised of the applicable legal principles, we are inclined to hold that they ignored the law or the evidence or both." $" 98$

The court also found that, though arbitrators generally are under no obligation to explain their award, the fact that no explanation was proffered here "can be taken into account" in this case in holding that the panel manifestly disregarded the law: "where a reviewing court is inclined to find that arbitrators manifestly disregarded the law or the evidence and that an explanation, if given, would have strained credulity, the absence of explanation may reinforce the reviewing court's confidence that the arbitrators engaged in manifest disregard." 99 Thus, while Halligan did not rely exclusively on manifest disregard of the evidence in vacating the arbitral award, it did, for the first time, introduce the concept of manifest disregard of the evidence as an alternative basis for vacating an arbitral award.

\section{B. Second Circuit Reactions To Halligan}

District courts within the Second Circuit wasted little time seizing on Halligan's "manifest disregard of the evidence" language as creating

94. Halligan, 148 F.3d at 203.

95. Id.

96. Id.

97. Id. at 203-04.

98. Halligan, 148 F.3d at 204 (emphasis added).

99. Id. 
an additional ground for vacating an arbitration award. The first case to adopt "manifest disregard of the evidence" as an independent basis for vacatur was Greenberg v. Bear Stearns \& Co., Inc. and Bear Stearns Securities Corp., where the court cited Halligan for the proposition that "[a] court may also modify or vacate an award if there is "strong evidence' contrary to the findings of the panel and the panel has not provided an explanation of its decision." 100 The Greenberg court found, however, that there was no manifest disregard of the evidence. ${ }^{101}$ Subsequent district court cases fleshed out the contours of this new doctrine. For example, in Beth Israel Medical Center v. Local 814, Intern. Broth. of Teamsters, the court echoed Greenberg's "strong evidence" language but cautioned that "the court may not re-weigh the evidence or question the credibility findings of the arbitrator." 102 Moreover, in Broome \& Wellington v. Levcor Int'l, Inc., the court opined: "even if [the party seeking vacatur] proves that the arbitrators' decision is based on a manifest error of fact or law, a court must nevertheless confirm the award if legitimate grounds for the decision can be inferred from the facts of the case." 103

Despite the plethora of cases finding that manifest disregard of the evidence was an independent basis for vacatur post-Halligan, ${ }^{104}$ only three decisions actually vacated an arbitration award. The first such decision, Daily News, L.P. v. Newspaper \& Mail Deliverers' Union of New York and Vicinity, involved an arbitration award affecting a wage increase for union workers at a newspaper. ${ }^{105}$ The newspaper sought to vacate an arbitrator's awarding of a significant pay increase to the union members on the ground that the arbitrator manifestly disregarded the fact that the newspaper could not afford to pay such a large increase. The court first rejected the union's claim that Halligan "does not extend the

100. No. 99 CIV. 358, 1999 WL 642859, at *1 (S.D.N.Y. Aug. 23, 1999).

101. Id. at **1-2.

102. No. 99 CIV. 9828,2000 WL 1364367 , at $* 6$ (S.D.N.Y. Sep. 20, 2000).

103. No. 02 Civ. 6566, 2003 WL 21032008 , at $* 2$ (S.D.N.Y. May 7, 2003) (citations omitted).

104. See, e.g., Raiola v. Union Bank Of Switzerland, LLC, 230 F. Supp. 2d 355, 358 (N.D. Ill. 1964); Hakala v. Deutsche Bank AG, No. 01 Civ. 3366, 2004 WL 1057788, at *5 (S.D.N.Y. May 11, 2004); Gwynn v. Clubine, 302 F. Supp. 2d 151, 167-68 (W.D.N.Y. 2004); Ono Pharmaceutical Co., Ltd. v. Cortech, Inc., No. 03 Civ. 5840 SAS, 2003 WL 22481379, at *2 (S.D.N.Y. Nov. 3, 2003); GFI Securities LLC v. Labandeira, No. 01 CIV. 00793, 2002 WL 460059, at *4 (S.D.N.Y. Mar. 26, 2002); see also McDaniel v. Bear Stearns \& Co., Inc., 196 F. Supp. 2d 343, (S.D.N.Y. 2002); Green v. Progressive Mgmt. Inc., No. 00 Civ. 2539, 2000 WL 1229755, at *2 (S.D.N.Y. Aug. 29, 2000).

105. No. 99 Civ. 5165, 1999 WL 1095613, at *7 (S.D.N.Y. Dec. 2, 1999). 
Second Circuit's manifest disregard standard to consideration of the evidence," stating "[t]his argument ignores the plain language of that case and diverges from the understanding of both academics and jurists." 106 Next, the court determined that the arbitrator failed to assess whether the newspaper could afford such a large increase in wages:

[T] he kind of thorough examination of the News's finances, which the large awarded wage increase made absolutely necessary, never occurred .... The Arbitrator entertained a relatively brief discussion of the financial problems of the News and looked at a summary of the profit-and-loss figures for the years 1993 through 1998. However, he declined to go into the details of the financial statements, including the cash flow statements. In the Final Award there was no finding of even the most conclusory nature with respect to the ability or inability of the News to pay the wage increases. Nor was any mention made of the prospect of the News staying in business or failing to stay in business if these increases were imposed."

The court held that the instant case was one of those limited situations in which an arbitration award must be vacated. ${ }^{108}$ As a result, the court held that "the Arbitrator manifestly disregarded evidence of the most critical nature," requiring that the arbitration award be vacated and remanded for factual findings on the issue of the newspaper's ability to pay. ${ }^{109}$

Manifest disregard of the evidence formed the basis for vacatur as well in Tripi v. Prudential Securities, Inc. ${ }^{110}$ In Tripi, the movant had been awarded compensatory damages in a securities arbitration below but sought to vacate the award on the grounds that the damages awarded were insufficient. The movant, who had been awarded $\$ 25,000$ in damages in an award lacking any explanation, claimed he was entitled to recover over $\$ 800,000$ for the diminution in value of his account holdings. The court noted that, "[w]hile the record is replete with evidence of Prudential's liability, there is also evidence supporting a

106. Id. at *7 (citing Carroll E. Neeseman \& Maren E. Nelson, Securities Arbitration Damages, Practicing Law Institute, 1131 PLI/Corp. 683, 756 (July-August 1999); Greenberg, 1999 WL 642859 at *1).

107. Id. at *8.

108. Id.

109. Daily News, 1999 WL 1095613 at *7, 9 .

110. 303 F. Supp. 2d 349 (S.D.N.Y. 2003). 
reduction of the claimed damages." ${ }^{111}$ Despite this, the court stated that "it is hard to imagine any justification for the arbitrators' award, which holds Prudential responsible for only three percent of Tripi's losses. The arbitrators have provided no clue as to how they arrived at a 97/3\% split."112 The court noted that the Panel declined to provide an explanation when Tripi asked the Panel for one and that Prudential failed to elucidate any facts in the record supporting "such a bizarre award." 113 The court concluded by stating:

[T]he Court cannot discern how the Panel arrived at such a disproportionate allocation of liability. Such a meager award shocks the conscience of this Court .... In light of the highly deferential standard due an arbitral award, however, I will remand to the Panel with instructions that it explain its allocation of damages. ${ }^{114}$

Finally, manifest disregard of the evidence served as the basis for vacatur in Wallace $v$. Buttar. ${ }^{115}$ As will be discussed in more detail below, the arbitration panel had awarded the Buttars compensatory and punitive damages for being fraudulently induced to purchase certain stocks by members of a brokerage firm. The district court vacated this award based on both manifest disregard of the law and manifest disregard of the evidence. Specifically, the court held that certain defendants could not have been liable for fraud because fraud requires a finding of culpable intent, yet the "totality of the evidence . . . overwhelmingly indicates" that these defendants never took part in any of the transactions underlying the Buttars' claims, let alone doing so with an intent to deceive. ${ }^{16}$ As a result, "the arbitrators could not have found that [these defendants] possessed the requisite intention to defraud the Buttars without manifestly disregarding this evidence, or lack of evidence."117 The district court also held that the finding that these individuals were "control persons" for purposes of liability under federal and state securities law constituted manifest disregard of the facts. The

\footnotetext{
111. Id. at 354.

112. Id. at 355 .

113. Id. at 355-56.

114. Tripi, 303 F. Supp. 2d at 356.

115. 239 F.Supp.2d 388 (S.D.N.Y. 2003), rev'd, 378 F.3d 182 (2d Cir. 2004).

116. Id. at 394.

117. Id. at 394-95.
} 
court stated that under federal law, a person must have the de facto power to direct the management and policies of a person to be a control person for that person's conduct, yet the Buttars failed to assert any such de facto control. ${ }^{118}$ As a result, the court vacated the arbitration award.

Many of these cases upholding the existence of manifest disregard of the evidence as a new ground for vacatur, including Tripi and Buttar, were issued subsequent to Second Circuit warnings that no such independent ground existed. For example, in Westerbeke Corp. $v$. Daihatsu Motor Co., the court opined:

We recognize that this Court has previously suggested in dicta that an award could be vacated where the arbitrators "manifestly disregarded ... the evidence" presented during the arbitration proceeding. See Halligan, 148 F.3d at 204. Halligan presented the special circumstance in which the arbitration tribunal did not issue a written explanation of its factual findings. The reviewing court was therefore placed in the situation of attempting to discern what possible findings the arbitrators could have made that would justify their disposition of the case. Unable to come up with any findings that would not "strain credulity," the court concluded that the tribunal must have "manifestly disregarded the law or the evidence or both." Halligan does not stand for the proposition that factual findings put on the record by the arbitrator are subject to an independent judicial review, however. ${ }^{119}$

Likewise, in The GMS Group, LLC v. Benderson, ${ }^{120}$ the Second Circuit clarified the limited holding of Halligan. The movant had claimed that Halligan stood for the proposition that an award should be vacated where there is "strong" or "overwhelming" evidence in the movant's favor. ${ }^{121}$ The court rejected this description, noting that the Halligan holding was limited to where there was (1) no dispute about the governing law and the law had been brought to the arbitrators' attention; (2) no written opinion containing findings of fact; and (3) overwhelming and strong evidence of "legally dispositive facts." 22 In such circumstances, the court opined, "we could only conclude that the [arbitrators] had disregarded [the law], as any other explanation would strain credulity given the quantity and quality of evidence of these facts.

118. Id. at 396-97.

119. 304 F.3d 200, 214 n. 9 (2d Cir. 2002).

120. 326 F.3d 75 (2d Cir. 2003).

121. Id. at 79 .

122. Id. 
We stress, again, that we reached this conclusion applying the traditional manifest disregard standard."123

Indeed, at least one district court was listening closely to these shots across the bow. ${ }^{124}$ In Success Systems, Inc. v. Maddy Petroleum Equip., Inc. ${ }^{125}$ Judge Kravitz rejected the movant's claim that the Second Circuit recognized an independent "manifest disregard of the evidence" basis for vacatur. "While there is certainly language in Halligan that one might read as contemplating a manifest disregard of the evidence standard, the Second Circuit's recent decision in GMS Group makes it clear that Halligan did no such thing." 126 In addition to clarifying that manifest disregard of the evidence was not an independent basis for vacatur, Judge Kravitz explained why manifest disregard of the evidence should not be an independent basis: "if manifest disregard of the evidence were an available ground for vacatur, courts would inevitably be asked to second-guess the arbitrators' factual decisions and, in effect, to retry the case, thereby depriving the parties of the simplicity for which they bargained."127

\section{Buttar Rejects Manifest Disregard Of The Evidence As An Independent Basis For Vacatur}

In Buttar, the Second Circuit finally resolved the meaning of its earlier decision in Halligan by reversing the district court's holding of manifest disregard. As noted, supra, an arbitration panel had awarded the Buttars compensatory and punitive damages against members of a brokerage firm, including the appellant "control persons," on the basis of joint and several liability for securities fraud. ${ }^{128}$ And, as discussed supra, the district court had vacated the award on the grounds that the award evinced manifest disregard of the law and the evidence.

The Second Circuit began its review of the decision below by reciting the "severely limited" nature of the doctrine of manifest

123. Id. (citation omitted).

124. See also Wedbush Morgan Securities, Inc. v. Robert W. Baird \& Co., 320 F. Supp. 2d 123, 127 n.4 (S.D.N.Y. 2004) (calling into question whether manifest disregard of the evidence constitutes an independent basis for vacatur).

125. 316 F. Supp. 2d 93 (D. Conn. 2004).

126. Id. at 97 .

127. Id. at 98 .

128. See supra, Part 3. 
disregard of the law, noting that the arbitral award should be enforced "if there is a barely colorable justification for the outcome reached." 129 The court then addressed the district court's statement that an arbitral award may be vacated on the ground of "manifest disregard of the facts" when the award "runs contrary to strong evidence favoring the party bringing the motion to vacate." 130 The court noted that many other district courts, in reliance on Halligan, had likewise advanced "manifest disregard of the facts" as an independent ground for vacatur. ${ }^{131}$ The court flatly rejected this position, stating that "[s]uch reliance is mistaken." court reviewed its holding in Halligan and pointed out that the court's subsequent decisions in GMS Group and Westerbeke had "cautioned against an over-broad reading of Halligan" and had "characterized Halligan's suggestion that arbitral awards may be vacated on the ground of manifest disregard of evidence as dicta." 133

The court also pointed out that

if a federal court is convinced that an arbitral panel has reached a merely incorrect legal result-that is based upon an irrational application of a controlling legal principle-the court should not conduct an independent review of the factual record presented to the arbitral panel in order to achieve the "correct' result."134

The court summarized federal court review of arbitration findings of fact as follows:

In sum, the Second Circuit does not recognize manifest disregard of the evidence as proper ground for vacating an arbitrator's award. We recognize only the doctrine of manifest disregard of the law, which doctrine holds that an arbitral panel's legal conclusions will be confirmed in all but those instances where there is no colorable justification for a conclusion. To the extent that a federal court may look upon the evidentiary record of an arbitration proceeding at all, it may do so only for the purpose of discerning whether a colorable basis exists for the panel's award so as to assure that the award cannot be said to be

129. Wallace v. Buttar, 378 F.3d 182, 189-90 (2d Cir. 2004) (emphasis and quotation omitted).

130. Id. at 191 (internal quotations omitted).

131. Id. at 191-92.

132. Id. at 192.

133. Buttar, 378 F.3d at 192.

134. Id. 
the result of the panel's manifest disregard of the law. ${ }^{135}$

The court did not, however, engage in the normative analysis conducted by Judge Kravitz as to why manifest disregard of the evidence was an unwise basis for vacatur. Because the Buttars had presented the panel with the law for control persons and punitive damages, and because the facts alleged provided a colorable justification for the award, the court held that the award should be confirmed. ${ }^{136}$

\section{Buttar's Implications For Federal Review Of Arbitral Findings Of Fact}

Both district courts ${ }^{137}$ and commentators ${ }^{138}$ quickly held Buttar out as pronouncing the death-knell for federal court review of arbitral panel findings of fact. A closer review of Judge Pooler's decision, however, indicates that there still may be ways for private parties to challenge arbitral findings of fact in federal court.

Buttar certainly marks the end of any independent ground for vacatur based on the doctrine of manifest disregard of the evidence. ${ }^{139}$ Yet Judge Pooler left a significant loophole in her decision by allowing federal courts to review the evidentiary record in an arbitration proceeding "for the purpose of discerning whether a colorable basis exists for the panel's award so as to assure that the award cannot be said to be the result of the panel's manifest disregard of the law." Unfortunately for practitioners and district courts alike, Judge Pooler did

135. Id. at 193 (quotation marks omitted).

136. Id. at 193-97.

137. E.g., Moorning-Brown v. Bear, Stearns \& Co., No. 99 CV 4130, 2005 WL 22851, at *3 (S.D.N.Y. Jan. 5, 2005) ("In entertaining a motion to vacate an arbitral award, it is not for the Court to conduct an independent review of the factual record presented to the arbitrators.") (citing Buttar); see also Success Systems, Inc. v. Maddy Petroleum Equip., 316 F. Supp. 2d. 93, 98 (D. Conn. 2004) ("[T] he factual determinations of the arbitrators chosen by the parties are simply beyond the purview of the courts.") (citation omitted).

138. Department ADR Brief, Second Circuit Bars Evidence Challenge To Arbitration Awards, 22 ALTERNATIVES TO HIGH CosT LiTIG. 157, 157 (October 2004) (stating that Buttar "appears to eliminate the possibility that an evidentiary problem can get an arbitration award overruled.").

139. See, e.g., Buttar, 378 F.3d at 192-93.

140. Id. at 193. 
not elaborate on what this language meant. Decisions from the First and Ninth Circuits (the latter of which were cited by Buttar), ${ }^{141}$ however, may help shed light on the types of situations where facts are properly reviewable for purposes of the manifest disregard of the law analysis. ${ }^{142}$ For example, in American Postal Workers Union v. United States Postal Service ${ }^{143}$ the Ninth Circuit addressed whether an arbitrator's award of reinstatement of a post office employee should be vacated. According to the court, the "only logical inference which [could] be drawn from" the arbitrator's factual conclusions was that the employee had gone on strike against the post office for a brief period of time. ${ }^{144}$ The court also pointed out that 5 U.S.C. $\S 7311$ forbids an individual who has participated in a strike against the government from ever again holding a government position. ${ }^{145}$ Despite this prohibition and these factual conclusions, the arbitrator had determined that mitigating factors made the "penalty of discharge [] too severe" and therefore awarded the postal employee reinstated, albeit without back pay. ${ }^{146}$ The Ninth Circuit held that this award constituted manifest disregard of the law because it was premised upon the factual conclusion that the employee did not strike, a conclusion wholly irreconcilable with the factual record:

In light of the undisputed facts of this case, we could not confirm an award of arbitration simply because the arbitrator stated that Murphy did not strike. To confirm such an award in this case would be to confer upon the arbitrator unreviewable power to construe and apply section $7311 \ldots$ We cannot empower the arbitrator to nullify the mandates of Congress simply by stating that an individual did not strike when, as here, his actions, as presented in undisputed facts, constitute a strike for purposes of the section. 14

141. New Jersey also endorses this type of factual review of arbitral awards. Under New Jersey law, a court may vacate an arbitral award "[w]here the award was procured by corruption, fraud or undue means." N.J.S.A. 2A:24-8(a). The New Jersey Supreme Court has explained that "'undue means' ordinarily encompasses a situation in which the arbitrator has made an acknowledged mistake of fact or law or a mistake that is apparent on the face of the record." State Office Of Employee Relations v. Communications Workers Of America, 154 N.J. 98, 111 (1998) (citations omitted).

142. This type of factual review is distinct from the type of factual review specifically sanctioned by 9 U.S.C. $\S 11$, which empowers a federal court to modify or correct an arbitration award "[w]here there was an evident material miscalculation of figures...."

143. 682 F.2d 1280, 1284-86 (9th Cir. 1982).

144. Id. at 1283.

145. Id.

146. Id. at 1284 .

147. American Postal Workers Union, 682 F.2d at 1285. It bears noting that the Ninth 
Conversely, the court held that, assuming there was a strike, the award should be vacated because reinstatement would violate section 7311 and "courts cannot enforce an arbitrator's award if it requires the performance of an illegal act."148

In Coutee v. Barington Capital Group, L.P.,${ }^{149}$ the Ninth Circuit clarified the meaning of American Postal. The court first affirmed that manifest disregard of the facts was not an independent ground for vacatur. ${ }^{150}$ The court then cited American Postal for the proposition that "[i]n some circumstances, however, legally dispositive facts are so firmly established that an arbitrator cannot fail to recognize them without manifestly disregarding the law." ${ }^{\text {"151 }}$ The court then clarified the relationship between "legally dispositive facts" and the doctrine of manifest disregard of the law:

\begin{abstract}
American Postal stands for the unexceptional proposition that a federal court will not confirm an arbitration award that is legally irreconcilable with the undisputed facts. Moreover, American Postal recognizes that because facts and law are often intertwined, an arbitrator's failure to recognize undisputed, legally dispositive facts may properly be deemed a manifest disregard for the law."152
\end{abstract}

The court did not, however, provide any additional examples of what it meant by "legally dispositive facts."

The First Circuit has also affirmed the propriety of judicial inquiry into the adequacy of legally dispositive facts, though using an alternative nomenclature. As explained in North Adams Regional Hosp. $v$. Massachusetts Nurses Ass'n., "153 "an arbitral award may be challenged on a showing that the award was "mistakenly based on a crucial assumption that is concededly a non-fact.", 154 The court clarified that the

Circuit pointed out that this was not the typical arbitration between two private parties because this arbitration "also requires an adjudication of the coverage and application of a federal law . ... We therefore cannot treat the issues raised by this dispute merely as matters of conflict between an employer and its employees." Id.

148. Id. at 1286.

149. 336 F.3d 1128 (9th Cir. 2003).

150. Id. at 1133 .

151. Id.

152. Id.

153. 74 F.3d 346 (1st Cir. 1996).

154. Id. at 348 (citations omitted). 
somewhat awkward phrasing "non-fact" refers to a situation "where the central fact underlying an arbitrator's decision is concededly erroneous," that is, where "there was a gross mistake . . . made out by the evidence, but for which, according to the arbitrator's rationale, a different result would have been reached." 155

For example, in Electronics Corp., the First Circuit was faced with an arbitration award reinstating an employee on the basis of the employer's failure to have suspended the employee as an intermediate step prior to termination. ${ }^{156}$ Reviewing the record, however, the court found that the employee clearly had been suspended prior to termination. ${ }^{157}$ The court therefore found the award unsustainable, holding that "where the 'fact' underlying an arbitrator's decision is concededly a non-fact and where the parties cannot fairly be charged with the misapprehension, the award cannot stand." 158

Thus, even after Buttar, it appears likely that federal courts within the Second Circuit remain free to examine the evidentiary record to discern whether "legally dispositive facts" or "non-facts" that contradict the arbitral award in light of the applicable law are so clearly established that the award constitutes manifest disregard of the law.

\section{CONCLUSION: DOES IT REALLY MATTER?}

The Second Circuit noted in Duferco that it had vacated an award for manifest disregard of the law in only four of the forty-eight (at least) cases that had raised the issue since $1960,{ }^{159}$ and its decision in Hardy was the fifth. ${ }^{160}$ The court also observed that all but one of these cases

155. Id. (quoting Electronics Corp. of Am. v. Int'l Union of Electrical Workers, Local 272, 492 F.2d 1255, 1256-57 (1st Cir. 1974) (internal quotation omitted)).

156. Electronics Corp. of Am. v. Int'l Union of Electrical Workers, Local 272, 492 F.2d $1255,1256-57$ (1st Cir. 1974).

157. Id. at 1256 .

158. Id. at 1257.

159. Duferno Int'l Steel Trading v. Klaveness Shipping A/S, 333 F.3d 383, 389 (2d Cir. 2003).

160. See Hardy v. Walsh Manning Securities, L.L.C., 341 F.3d 126, 134 (2d Cir. 2003) (remanding to arbitration for clarification where arbitral panel improperly based liability of a fellow employee on respondeat superior, a doctrine only applicable against employers, and made no finding as to employee's personal liability); N.Y. Tel. Co. v. Communication Workers of Am., 256 F.3d 89, $92-93$ (2d Cir.2001) (per curiam) (vacating portion of award where 
could have been decided identically under the exceeding authority standard. In Fahnestock \& Co., Inc. v. Waltman, ${ }^{161}$ for example, the court vacated an arbitral award of punitive damages where New York law, which governed, prohibited such damages in arbitration. The court did not rest its holding on manifest disregard grounds but rather on the arbitrators' lack of power to enter such awards. ${ }^{162}$

The Sixth Circuit has painted an even bleaker picture for litigants hoping to succeed on manifest disregard grounds. "Since Supreme Court dictum established the manifest disregard of the law standard forty-seven years ago, only two federal courts of appeals have used it to vacate arbitration decisions." ${ }^{\prime 163}$ Many state courts are similarly reluctant to vacate on account of manifest disregard. ${ }^{164}$

But the doctrine is not unimportant on account of its infrequent application. Its explication has reminded courts of the deference owed arbitrations, and the reason for and limits of that deference. And in those few cases where it has been used, it has, arguably, prevented unjust public enforcement proceedings.

Cases such as Halligan, American Postal, and Electronics Corp., where vacatur has been granted, seem to affirm the hints in Hoeft and Kyocera of some latent due process concerns about arbitration, whether imposed directly by judges despite the FAA or properly derived from the FAA. Whatever the source, it is likely that a sense of fundamental

arbitrator explicitly rejected circuit precedent in favor of the rule of another circuit); Halligan v. Piper Jaffray, Inc., 148 F.3d 197, 204 (2d Cir. 1998), cert. denied, 119 S.Ct. 1286 (1999) (finding manifest disregard in an age discrimination case in which the evidence was overwhelmingly against the unexplained arbitral decision); Fahnestock \& Co., Inc. v. Waltman, 935 F.2d 512, 519 (2d Cir. 1991); Perma-Line Corp. of Am. v. Sign Pictorial \& Display Union, 639 F.2d 890, 894-96 (2d Cir.1981) (holding that it could not confirm an award that violated public policy in that it was based on a "presumptively illegal" provision in a collective bargaining contract).

.161. 935 F.2d 512, 517-19 (2d Cir.1991).

162. Id. Though it brushed aside a couple of manifest disregard arguments of the petitioner-appellant, the court did not use the phrase manifest disregard in affirming the vacatur the punitive damages award against it. Instead, it referred to the arbitrators' lack of power to grant such damages under New York law and vacated pursuant to what is now § 10(a)(4) of the FAA. Id. Numerous other courts have blurred review for manifest disregard and exceeding authority. See, e.g., Missouri River Servs., Inc. v. Omaha Tribe of Neb., 267 F.3d 848, 854-55 (8th Cir. 2001) (using the language of both exceeding authority and manifest disregard to conclude that an arbitral remedy that was contrary to that specified in the contract must be vacated).

163. Dawahare v. Spencer, 210 F.3d 666, 671 (6th Cir. 2000) (citation omitted).

164. Despite adopting manifest disregard of the law as a ground for vacatur, see Garrity v. McCaskey, 223 Conn. 1, 11 (1992), and the Second Circuit's standard for applying the doctrine, the Connecticut courts have never sustained the vacatur of an award on this ground. 
fairness weighs on judges' minds, making patently unfair arbitration awards simply too much for judges to confirm. It may not be until the Supreme Court goes beyond dicta to explain the doctrine or, for example, when a circuit court is faced with a case involving conflict preemption of a state rule barring manifest disregard review, that the pieces come together more clearly to define in greater detail the source and scope of manifest disregard review. Nevertheless, the recent decisions discussed in this article suggest that, despite the pressure to be highly deferential to arbitral rulings, judges are not willing to abdicate total control to arbitrators. 
HeinOnline -- 24 QLR 832 2005-2006 